\title{
Penerapan Konseling Behavioral Teknik Modelling Untuk Mengatasi Kecanduan Game Online Pada Anak Usia 10 Tahun
}

\author{
Didik Gunawan \\ Bimbingan dan Konseling - Universitas Darul Ulum Jombang, Jawa Timur \\ dgunawan114@gmail.com
}

Submitted: 05-10-2018, Revised : 24-11-2018, Accepted : 24-12-2018

\begin{abstract}
Addiction to online games is an excessive behavior to play online games that have an impact on the formation of maladaptive behavior, not in accordance with the norms prevailing in the community. Counseling behavioral modeling techniques is one of the services that are considered appropriate to overcome online game addiction problems. The purpose of this study is to determine whether counseling behavioral modeling techniques can be applied to overcome online game addiction in children aged 10 years. The type of research used by researchers is the type of single subject research, using the $A-B$ research design $(A=$ baseline condition, $B=$ intervention condition). A-B shows two stages of design; $A$ is baseline data (pretest) and $B$ is intervention (posttest). The results showed that behavioral counseling modeling techniques were effective for reducing online game addiction in children aged 10 years.
\end{abstract}

Keywords: Behavioral Modeling Counseling, Game Online Addiction

\begin{abstract}
Abstrak: Kecanduan game online merupakan perilaku berlebihan untuk melakukan permainan secara online yang berdampak terhadap pembentukan perilaku maladaptif, tidak sesuai norma yang berlaku di masyarakat. Konseling behavioral teknik modelling merupakan salah satu layanan yang dipandang tepat untuk mengatasi permasalahan kecanduan game online. Tujuan dari penelitian ini adalah untuk mengetahui apakah konseling behavioral teknik modelling dapat diterapkan untuk mengatasi kecanduan game online pada anak usia 10 tahun. Jenis penelitian yang dipakai peneliti adalah jenis penelitian singel subjek, dengan menggunakan desain penelitian A-B ( $\mathrm{A}=$ kondisi baseline, $\mathrm{B}=\mathrm{kondisi}$ intervensi). A-B menunjukkan dua tahapan dari desain; A adalah data baseline (pretest) dan B adalah intervensi (posttest). Hasil penelitian menunjukkan bahwa konseling behavioral teknik modelling efektif untuk menurunkan kecanduan game online pada anak usia 10 tahun.
\end{abstract}

Kata Kunci: Konseling Behavioral Teknik Modelling, Kecanduan Game Online

\section{Pendahuluan}

Perkembangan teknologi berupa internet memberikan manfaat yang sangat besar bagi kemajuan di segala bidang kehidupan. Hari ke hari internet menyuguhkan banyak penawaran yang menarik, alih-alih menggunakan internet untuk menyelesaikan tugas kuliah atau pekerjaan, kenyataannya banyak yang beralih pada game online (Prastyo, 2017).

Bermain adalah unsur yang penting untuk perkembangan anak baik fisik, emosi, mental, intelektual, kreativitas, dan sosial (Sanditaria, 2012). Anak usia sekolah adalah usia berkelompok atau sering disebut sebagai usia penyesuaian diri (Hurlock, 1980). Pada saat anak berusia sepuluh tahun, permainannya terutama bersifat persaingan, dengan pokok perhatian pada keterampilan dan keunggulan dan tidak semata-mata pada kegembiraan (Hurlock, 1980). Anak-anak masa sekolah mengembangkan kemampuan melakukan permainan (game) dengan peraturan yang berdampak pada timbulnya masalah seperti kenakalan (delinquency), inferioritas, tidak percaya diri, sering mengkritik diri sendiri, dan bahkan merasa tidak berharga yang akan menurunkan harga dirinya (Habsy, 2017b).

Seiring dengan pesatnya perkembangan teknologi internet, game online juga mengalami perkembangan yang pesat. Game online adalah game yang berbasis elektronik dan visual (Sanditaria, 2012). Berbagai jenis game online bisa diakses oleh para pengguna smartphone melalui playstore atau googleplay.

Banyak kalangan yang menggandrungi game online. Mulai dari kalangan pelajar hingga mahasiswa. Mulai dari anak-anak hingga dewasa. Tidak sedikit mereka yang mulai 
kecanduan game tersebut. Menurut Smart ciri-ciri seorang anak yang sudah kecanduan internet umumnya antara lain : (a) merasa terikat dengan game online (memikirkan mengenai aktivitas online pada saat sedang offline atau mengharapkan sesi online berikutnya, (b) memainkan game online dengan lama waktu lebih dari 14 jam per minggu dan hanya memainkan satu jenis/tipe game saja, (c) merasa kebutuhan bermain game online dengan jumlah waktu yang terus meningkat untuk mencapai sebuah kegembiraan yang diharapkan, (d) merasa gelisah, murung, depresi, atau lekas marah ketika mencoba untuk mengurangi atau menghentikan bermain game online, (e) berbohong pada anggota keluarga, terapis atau orang lain untuk menyembunyikan seberapa jauh terlibat dengan game online, (f) bermain game online sebagai suatu cara untuk melarikan diri dari masalah-masalah atau untuk mengurangi suatu kondisi perasaan yang menyusahkan (misal perasaan-perasaan tidak berdaya, bersalah, cemas, stres dan depresi)(Santoso, 2016).

Seseorang yang mengalami kecanduan game online akan mengalami beberapa gejala seperti salience (berpikir tentang bermain game online sepanjang hari), tolerance (waktu bermain game online yang semakin meningkat), mood modification (bermain game online untuk melarikan diri dari masalah), relapse (kecendrungan untuk bermain game online kembali setelah lama tidak bermain), withdrawal (merasa buruk jika tidak dapat bermain game online), conflict (bertengkar dengan orang lain karena bermain game online secara berlebihan), dan problems (mengabaikan kegiatan lainnya sehingga menyebabkan permasalahan). Tujuh kriteria kecanduan game online ini merupakan pengukuran untuk mengetahui kecanduan atau tidaknya seorang pemain game online yang ditetapkan pemain yang mendapatkan empat dari tujuh kriteria merupakan indikasi pemain yang mengalami kecanduan game online (Prastyo, 2017).

Berdasarkan studi pendahuluan yang dilakukan melalui wawancara pada tanggal 21 Maret 2018 kepada pihak keluarga yang anaknya mengalami kecanduan game online didapatkan data bahwa ada perbedaan perilaku yang muncul ketika anak tersebut tengah berkonsentrasi dengan game onlinenya. Seperti contohnya, ketika anak tersebut sedang asyik dengan gamenya dan orang tuanya menyuruh untuk melalukan sesuatu maka anak tersebut tidak segera melakukan apa yang diperintahkan oleh orang tuanya melainkan dia lebih mementingkan gamenya terlebih dahulu. Selain itu, perubahan perilaku yang muncul dari anak tersebut adalah apabila neneknya memberi nasihat tentang suatu hal kepada yang bersangkutan maka anak tersebut memberikan respon yang kurang baik, bukan mendengarkan nasihat yang diberikan dengan baik tetapi malah anak memberikan semacam sanggahan berupa candaan atau godaan kepada neneknya. Dengan hasil yang didapat dari wawancara tersebut maka peneliti memandang adanya perubahan perilaku yang muncul dari anak yang kecanduan game online tersebut dengan indikator yang sebagaimana disajikan diatas.

Menurut Skinner (dalam Maulana, 2012), merumuskan bahwa perilaku merupakan respon atau reaksi seseorang terhadap stimulus atau rangsangan dari luar. Oleh karena perilaku ini terjadi melalui proses adanya stimulus terhadap organisme, dan kemudian organisme tersebut merespons, maka teori Skinner ini disebut teori "S-O-R" atau Stimulus-OrganismeRespon(Maulana, 2012).

Dengan demikian maka peneliti memandang seorang anak yang mengalami kecanduan game online akan berdampak pula terhadap perilaku baru yang muncul dari akibat kecanduan game online yang hal itu selaras dengan hasil studi pendahuluan diatas. Hal tersebut semakin diperkuat dari penelitian sebelumnya tentang berisi tentang "Pengaruh Game Online Terhadap Perubahan Perilaku Agresif Remaja Di Samarinda" yang menyebutkan bahwa ada pengaruh game online terhadap perubahan perilaku agresif remaja di Samarinda(Amanda, 2016). Senada dengan Amanda, Pengaruh Game Online Terhadap Perubahan Perilaku Anak SMP 1 Samboja didapatkan hasil bahwa terdapat pengaruh dengan bermain game online terhadap perubahan perilaku siswa SMP 1 Samboja (Kutai Kartanegara)(Fauziah, 2013). 
Perilaku yang demikian merupakan salah satu perilaku maladaptif (salah suai). Perilaku maladaptif adalah perilaku yang tidak sesuai dengan situasi sosial yang ada di lingkungan sekitar individu, apabila perilaku yang salah suai ini dibiarkan tetap ada didalam diri anak, maka dikhawatirkan akan menjadi satu kebiasaan perilaku yang akan tetap muncul hingga dewasa nanti(Habsy, 2017b). Perilaku individu memiliki kecenderungan sejak lahir untuk tumbuh dan beraktualisasi, namun sering menyabotase kemajuannya sendiri karena pola pengalahan diri yang dipelajari (Habsy, 2018).

Melihat permasalahan yang semacam ini, menjadi satu kewajiban sebagai seorang guru BK untuk melakukan konseling untuk menyelesaikan permasalahan tersebut. Konseling dalam lingkup pendidikan merupakan upaya penanganan masalah dalam rangka memfasilitasi perkembangan individu dalam lingkungannya yang tertuju pada upaya menciptakan kondisi optimum bagi perkembangan individu(Habsy, 2017a).

Ada berbagai macam pendekatan dan teknik konseling yang dapat digunakan untuk melalukan proses konseling. Salah satu diantaranya adalah pendekatan konseling behavioral dengan teknik modelling. Terapi tingkah laku adalah penerapan aneka ragam teknik dan prosedur yang berakar pada berbagai teori tentang belajar. Terapi ini menyertakan penerapan yang sistematis prinsip-prinsip belajar pada perubahan tingkah laku ke arah cara-cara yang lebih adaptif(Corey, 2013).

Dalam penerapan teknik modelling, konseli dihadapkan dengan model baik model orang atau model audio video yang bisa menjadi stimulus kepada konseli untuk memunculkan respon meniru apa yang dilakukan model. Hal ini yang menjadi motivasi saya untuk mengadakan penelitian dengan judul "Penerapan Konseling Behavioral Teknik Modelling Untuk Mengatasi Kecanduan Game Online Pada Anak Usia 10 Tahun.

\section{Metode Penelitian}

Jenis penelitian yang dipakai peneliti adalah jenis penelitian singel subjek (Single Subject Riset/SSR). SSR adalah desain eksperimental yang melibatkan penyidikan intensif terhadap satu atau beberapa individu, yang mana setiap perilaku individu pada kondisi yang satu dibandingkan dengan pada kondisi lainnya (Alberto \& Trouthman, 2006; Richards dkk., 1999; Tawney \& Gast, 1984). SSR merupakan metodologi praktis untuk mengevaluasi kemajuan akademik, mengembangkan perilaku sosial, menurunkan masalah perilaku, dan meningkatkan keterampilan guru (orangtua) yang melaksanakan intervensi(Runtukahu, 2013).

Penelitian yang dilakukan peneliti ini adalah bertujuan untuk mengatasi kecanduan game online pada anak usia 10 tahun dengan konseling behavioral teknik modelling. Desain atau rancangan penelitian merupakan suatu proses yang diperlukan dalam perencanaan dan pelaksanaan sebuah penelitian(Habsy, 2017c). Dalam penelitian ini, peneliti memakai desain penelitian A-B. desain A-B adalah dasar SSR (A=kondisi baseline, B=kondisi intervensi). A$\mathrm{B}$ menunjukkan dua tahapan dari desain; A adalah data baseline (pre test) dan $\mathrm{B}$ adalah intervensi (post test).

Proses pengukuran pada penelitian ini dilakukan sebanyak dua kali yaitu sebelum dan sesudah pemberian perlakuan dengan menggunakan instrumen yang sama yaitu konseling behavioral teknik modelling. Untuk memperjelas eksperimen yang akan dilakukan peneliti, disajikan langkah-langkah sebagai berikut:

\section{a. Penggalian Data A (Baseline)}

Data baseline mencatat tingkat perilaku (variabel dependen) seperti adanya sebelum dilakukan intervensi. Maksud dari penggalian data baseline ini adalah untuk mengetahui seberapa sering subjek penelitian ini melakukan bermain game online serta apa saja dampak ke perilaku subjek saat sedang bermain game online. Data baseline dapat disamakan dengan pre-test. Penggalian data ini dilakukan dengan cara melakukan wawancara dengan pihak keluarga subjek untuk 
memperoleh informasi bagaimana aktifitas subjek kaitannya dengan game online dan perilaku. Kisi-kisi wawancara dimuat dalam tabel 1 dan 2.

Tabel 1. Kisi-kisi wawancara perihal game online

\begin{tabular}{clcc}
\hline No. & \multicolumn{1}{c}{ Komponen } & Jumlah Item & Nomor Item \\
\hline 1. & Selalu ingin bermain game & 2 & 1,2 \\
2. & Ingin bermain game dengan waktu yang lama & 1 & 3 \\
& & 1 & 4 \\
3. & Merasa senang jika bermain game & 2 & 5,6 \\
4. & Merasa cemas jika tidak bermain game & 2 & 7,8 \\
5. & Kurang nyaman jika diganggu saat bermain game & & \\
\hline
\end{tabular}

Tabel 2 Kisi-kisi wawancara perihal dampak game terhadap perilaku

\begin{tabular}{clcc}
\hline No. & \multicolumn{1}{c}{ Komponen } & Jumlah Item & Nomor Item \\
\hline 1. & Berkelahi dengan saudara karena game & 1 & 1 \\
2. & Berbohong karena game & 1 & 2 \\
3. & Malas-malasan karena game & 2 & 3,4 \\
4. & Kurang memperhatikan nasihat orang tua karena game & 1 & 5 \\
\hline
\end{tabular}

b. Penggalian Bata B (Intervensi)

Komponen penting lain dalam desain subjek tunggal adalah terdapat seri data perilaku subjek setelah diberlakukan intervensi. Variabel independen (intervensi) dan diberlakukan dan variabel dependen diukur dan dicatat. Tren data akan mengindikasikan efektivitas intervensi yang memungkinkan guru atau peneliti untuk mengubah prosedur intervensi dan kontrol eksperimental. Kontrol eksperimental merujuk pada upaya guru atau peneliti untuk memutuskan apakah terdapat hubungan fungsional antarperubahan independen dan variabel dependen. Dalam hal ini, intervensi yang diberikan peneliti terhadap subjek adalah berupa konseling behavioral teknik modelling.

Gambar desain penelitian konseling behavioral teknik modelling untuk mengatasi kecanduan game online pada anak usia 10 tahun (masa akhir kanak-kanak) dapat divisualisasikan pada gambar 1 . 


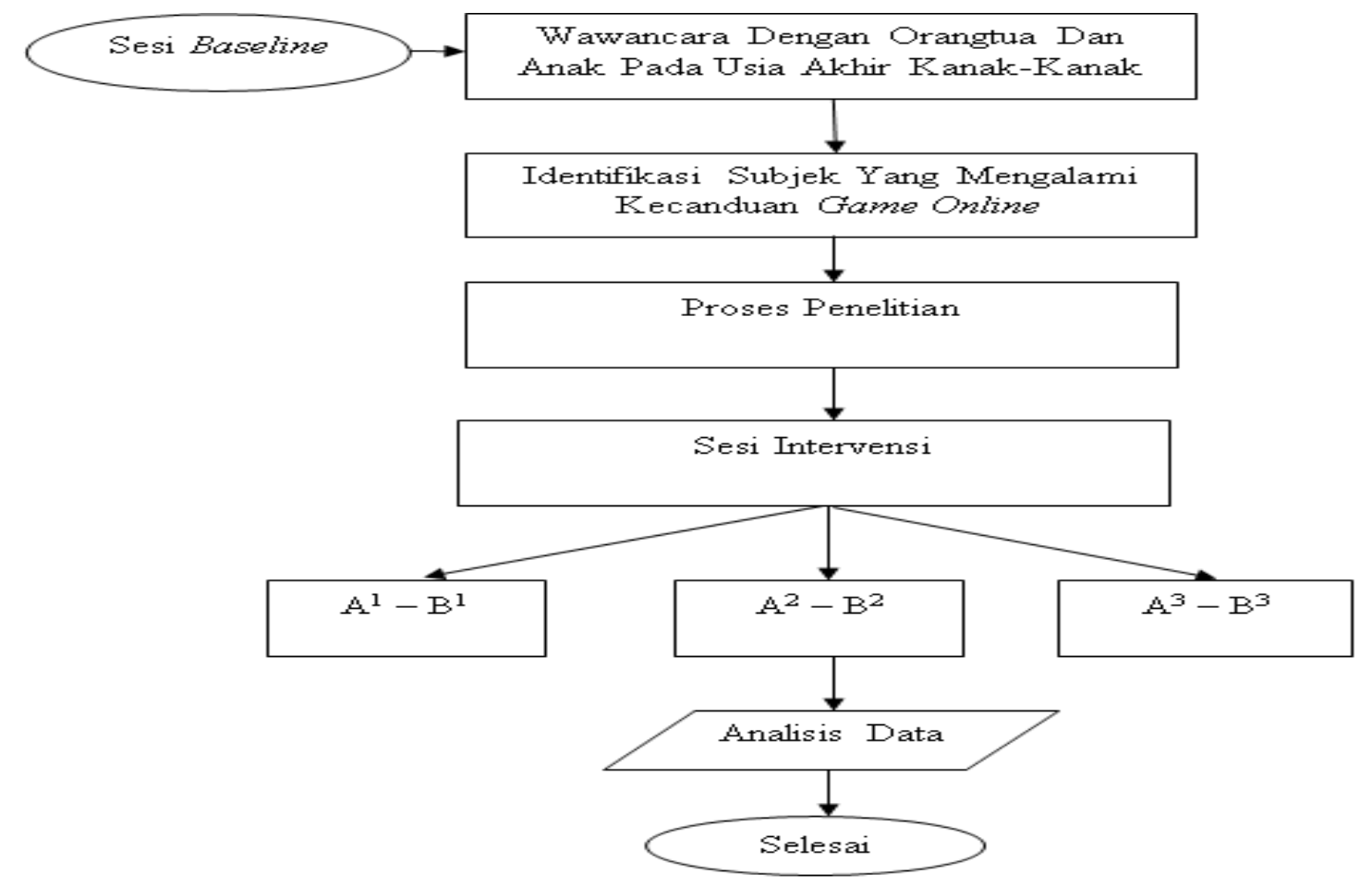

Gambar 1. Desain Penelitian

Untuk melakukan analisis data, Sunanto, dkk (2005) menyebutkan bahwa analisis data merupakan tahap terakhir sebelum menarik kesimpulan. Pada penelitian eksperimen pada umumnya pada saat menganalisis data menggunakan teknik statistik deskriptif. Oleh karena itu pada penelitian dengan kasus tunggal penggunaan statistik yang komplek tidak dilakukan tetapi lebih banyak menggunakan statistik deskriptif yang sederhana. Komponen dalam analisis data adalah panjang kondisi, perubahan untuk setiap vartiabel, level, dan kecenderungan.

\section{Hasil dan Pembahasan}

Penelitian ini dilaksanakan di Dusun Mojosulur RT 01/RW 03, Desa Mojosulur Kecamatan Mojosari Kabupaten Mojokerto. Di wilayah ini terdapat beberapa anak usia 6-11 tahun yang menjadi bagian dari penduduk. Dengan rincian sebagai berikut:

$\begin{array}{ll}\text { Laki-laki } & \text { Perempuan } \\ 14 \text { anak } & 4 \text { anak }\end{array}$

Penetapan subjek penelitian ini dimulai pada tanggal 21 Maret 2018, 8 Mei 2018 dengan melalukan wawancara kepada pihak keluarga serta teman-teman sepermainan subjek. Wawancara ini dilakukan untuk menggali data tentang bagaimana kehidupan subjek terutama yang berkaitan dengan seberapa sering subjek ini melalukan kegiatan bermain game online setiap harinya. Selain itu juga menggali informasi tentang dampak yang ditimbulkan ketika subjek ini melakukan kegiatan bermain game online terhadap pola perilaku anak kepada keluarga (orang tua atau saudara).

Setelah itu, peneliti melakukan wawancara langsung kepada subjek penelitian untuk memastikan seberapa sering subjek ini bermain game online dalam sehari yang kemudian dimasukkan dalam data pretest (data baseline), pada table 3 . 
Tabel 3. Hasil Data Baseline durasi bermain game online

\begin{tabular}{cc}
\hline $\begin{array}{c}\text { Baseline } \\
\text { Sesi }\end{array}$ & $\begin{array}{c}\text { Durasi Bermain Game Online } \\
\text { (dalam Jam) }\end{array}$ \\
\hline 1 & 6 \\
2 & 4,5 \\
3 & 5 \\
4 & 4,5 \\
5 & 5 \\
\hline
\end{tabular}

Dari data distribusi durasi diatas, maka dapat divisualisasikan dalam gambar 2 .

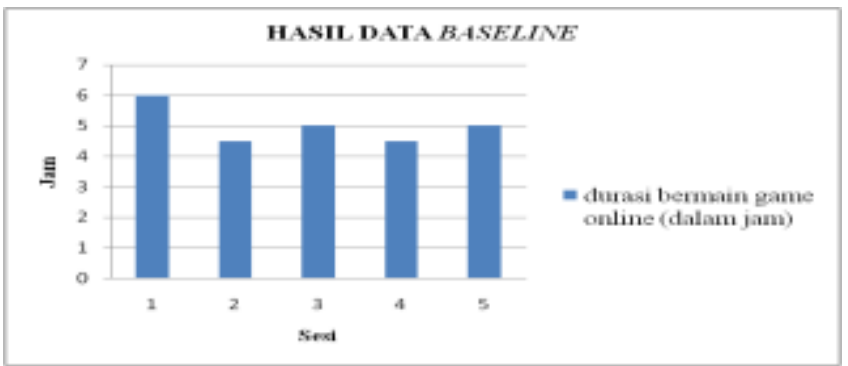

Gambar 2. Hasil Data Baseline durasi bermain game online

Selain melakukan wawancara dengan subjek langsung, peneliti juga melakukan wawancara dengan pihak keluarga subjek untuk mengetahui bagaimana dampak yang ditimbulkan ketika subjek melakukan aktifitas bermain game online ini terutama berkaitan dengan pola perilaku subjek, apakah ada perbedaan pola perilaku ketika subjek ini mengalami kecanduan game online. Hasil wawancara dengan pihak keluarga diperoleh data pada table 4.

Tabel 4. Hasil data baseline frekuensi berkelahi dengan anggota keluarga/saudara

\begin{tabular}{cc}
\hline $\begin{array}{c}\text { Baseline } \\
\text { Sesi }\end{array}$ & $\begin{array}{c}\text { Frekuensi berkelahi dengan } \\
\text { anggota keluarga/saudara }\end{array}$ \\
\hline 1 & 3 \\
2 & 3 \\
3 & 3 \\
4 & 3 \\
5 & 3 \\
\hline
\end{tabular}

Dari data frekuensi diatas, maka dapat divisualisasikan dalam gambar 3.

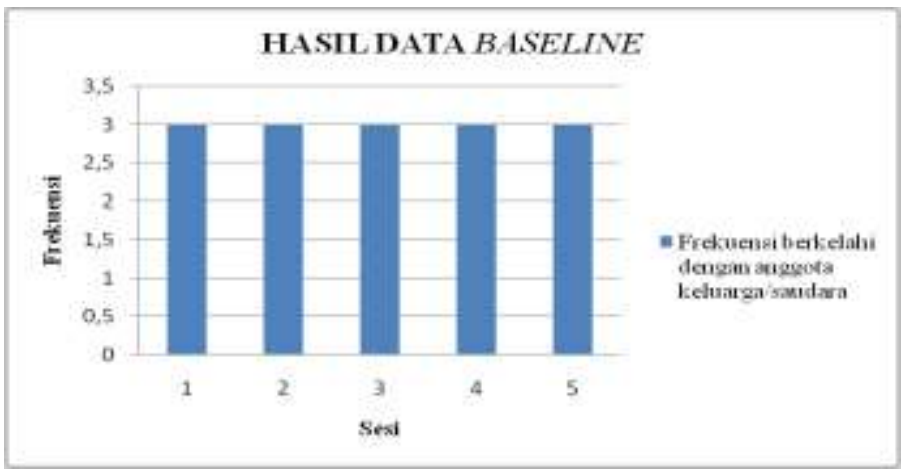

Gambar 3 Hasil data baseline frekuensi berkelahi dengan anggota keluarga/saudara 
Tabel 5. Hasil data baseline frekuensi berbohong kepada orang tua

\begin{tabular}{cc}
\hline $\begin{array}{c}\text { Baseline } \\
\text { Sesi }\end{array}$ & Frekuensi berbohong kepada orangtua \\
\hline $\mathbf{1}$ & 3 \\
$\mathbf{2}$ & 3 \\
$\mathbf{3}$ & 4 \\
$\mathbf{4}$ & 5 \\
$\mathbf{5}$ & 5 \\
\hline
\end{tabular}

Dari data frekuensi diatas, dapat divisualisasikan dalam gambar sebagai berikut:

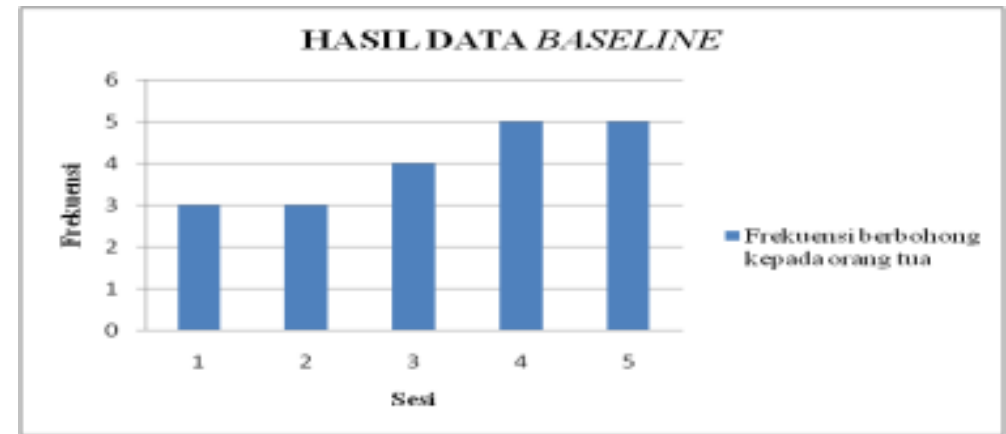

Gambar 4. Hasil data baseline berbohong kepada orang tua

Pelaksanaan proses intervensi berupa konseling behavioral teknik modelling terhadap subjek penelitian ini dilakukan sebanyak enam kali pertemuan dimulai pada tanggal 9 Mei 2018 sampai tanggal 25 Mei 2018. Dimana tidak setiap hari peneliti melakukan konseling melainkan dilakukan ketika peneliti memberikan bimbingan belajar kepada beberapa anak sekolah dasar yang didalamnya termasuk subjek penelitian. Sehingga proses konseling ini dilakukan di sela-sela setelah peneliti memberikan bimbingan belajar dan konseling dilakukan dengan durasi 30 menit tiap pertemuan.

Untuk rancangan proses konseling dari awal hingga akhir yang menjadi acuan peneliti memberikan konseling kepada subjek adalah peneliti berpijak dari tahap-tahap konseling behavioral yang meliputi: (1) Assesment, (2) Goal setting, (3) Teknik implementasi, (4) Evaluasi terminasi(Habsy, 2014). Dari tahap-tahap tersebut, peneliti mengaplikasikan dalam rancangan skenario tahap-tahap konseling kepada subjek penelitian pada table 6 .

Tabel 6. Rancangan proses intervensi (konseling behavioral teknik modelling)

\begin{tabular}{|c|c|c|c|}
\hline No. & Pertemuan & Materi Konseling & Waktu \\
\hline 1 & Pertama & $\begin{array}{l}\text { Melakukan assesment tentang tingkat kecanduan game } \\
\text { online }\end{array}$ & 30 menit \\
\hline 2. & Kedua & $\begin{array}{l}\text { Merumuskan tujuan dengan konseli tentang bagaimana } \\
\text { bahaya kecanduan game online }\end{array}$ & 30 menit \\
\hline 3. & Ketiga & $\begin{array}{l}\text { Mengimplementasikan teknik modelling berkaitan } \\
\text { dengan bahaya game online }\end{array}$ & 30 menit \\
\hline 4. & Keempat & $\begin{array}{l}\text { Mengimplementasikan teknik modelling berkaitan } \\
\text { dengan perubahan perilaku terhadap orangtua (berbohong } \\
\text { kepada orangtua dan mengabaikan nasehat orangtua) }\end{array}$ & 30 menit \\
\hline 5. & Kelima & $\begin{array}{l}\text { Mengimplementasikan teknik modelling berkaitan } \\
\text { dengan perubahan perilaku (malas-malasan dan berkelahi } \\
\text { dengan anggota keluarga atau saudara) }\end{array}$ & 30 menit \\
\hline 6 & Keenam & Melakukan follow up & 30 menit \\
\hline
\end{tabular}




\section{Pembahasan}

Penelitian yang dilaksanakan oleh peneliti adalah dengan menggunakan konseling behavioral teknik modelling untuk mengatasi dampak kecanduan game online pada anak usia 10 tahun (masa akhir kanak-kanak) dengan jenis penelitian subjek tunggal (single subject research). Pada penelitian ini, peneliti menerapkan konseling behavioral teknik modelling terhadap subjek penelitian saat proses treatment. Subjek penelitian didapatkan oleh peneliti dengan cara melakukan wawancara dengan berbagai sumber baik itu dari anak-anak usia 6-11 tahun yang ada disekitar lingkungan tempat tinggal peneliti beserta melakukan wawancara dengan pihak keluarga subjek penelitian yang bersangkutan untuk memperoleh informasi yang mendukung yang akan dijadikan data pendukung penelitian.

Berdasarkan wawancara yang dilakukan, peneliti mendapatkan satu anak yang memenuhi syarat dijadikan sebagai subjek penelitian. Dalam menentukan subjek penelitian, peneliti berpedoman pada teori yang disampaikan oleh Lemmens, Valkenberg, \& Peter (2009, dalam Prastyo, 2012) yang menyebutkan tujuh kriteria seorang anak mengalami kecanduan game online yakni (1) salience (berpikir tentang bermain game online sepanjang hari), (2) tolerance (waktu bermain game online yang semakin meningkat), (3) mood modification (bermain game online untuk melarikan diri dari masalah), (4) relapse (kecenderungan untuk bermain game online kembali setelah lama tidak bermain), (5) withdrawal (merasa buruk jika tidak bermain game online), (6) conflict (bertengkar dengan orang lain karena bermain game online secara berlebihan), (7) problem (mengabaikan kegiatan lainnya sehingga menyebabkan permasalahan). Dimana dari ketujuh kriteria tersebut, seseorang bisa dikategorikan sebagai kecanduan game online jika memenuhi empat kriteria yang ada.

Setelah mendapatkan data tentang aktivitas bermain game online dari subjek penelitian, peneliti juga melakukan penggalian data tentang bagaimana dampak kecanduan game online yang dialami oleh subjek terhadap perilakunya sehari-hari. Data ini didapatkan peneliti melalui wawancara dengan pihak keluarga subjek dalam hal ini nenek dari subjek penelitian. Data yang didapat peneliti dari wawancara tersebut menunjukkan bahwa ada dampak dari kecanduan game online terhadap perubahan perilaku yang dialami subjek penelitian.

Setelah mendapatkan data-data tersebut diatas, peneliti melakukan proses treatment dengan memberikan konseling behavioral teknik modelling mulai tanggal 9 Mei sampai 25 Mei 2018. Proses pemberian treatment tersebut dilakukan enam kali pertemuan dimana pertemuan dilakukan dirumah peneliti dengan durasi 30 menit setiap pertemuan. Dari hasil analisis data menggunakan metode penelitian subjek tunggal yang memperhatikan panjang kondisi, perubahan untuk variabel, level, dan kecenderungan data diketahui bahwa intervensi yang diberikan berupa konseling behavioral teknik modelling dapat mengubah perilaku kecanduan game online beserta perilaku terdampak game online secara bertahap. Adapun perilaku yang mengalami perubahan setelah mendapatkan intervensi adalah sebagai berikut:

1. Durasi bermain game online

Tabel 7. Hasil Data Baseline durasi bermain game online

\begin{tabular}{cc}
\hline $\begin{array}{c}\text { Baseline } \\
\text { Sesi }\end{array}$ & $\begin{array}{c}\text { Durasi Bermain Game } \\
\text { Online }\end{array}$ \\
\hline 1 & 6 \\
2 & 4,5 \\
3 & 5 \\
4 & 4,5 \\
5 & 5 \\
\hline
\end{tabular}


Tabel 8. Hasil Data Intervensi durasi bermain game online

\begin{tabular}{|c|c|}
\hline $\begin{array}{l}\text { Intervensi } \\
\text { Sesi }\end{array}$ & $\begin{array}{l}\text { Durasi Bermain Game } \\
\text { Online (dalam Jam) }\end{array}$ \\
\hline 1 & 4 \\
\hline 2 & 3,5 \\
\hline 3 & 3 \\
\hline 4 & 3 \\
\hline 5 & 2,5 \\
\hline
\end{tabular}

Data-data diatas jika divisualisasikan dalam bentuk grafik akan berbentuk seperti gambar dibawah ini:

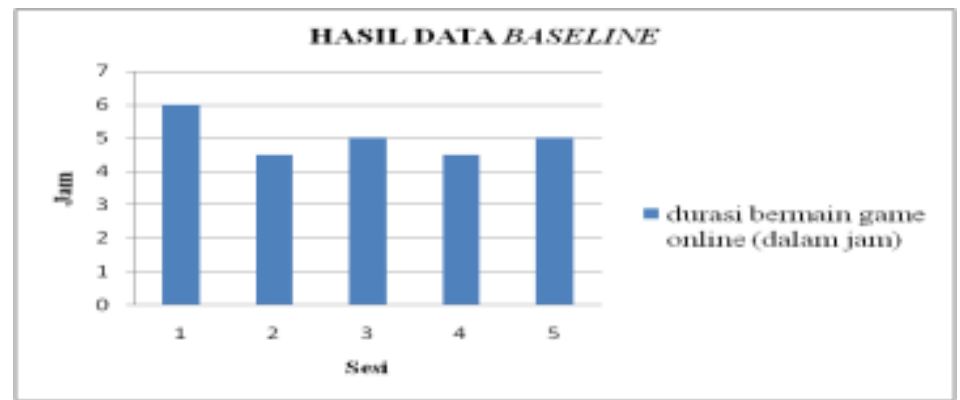

Gambar 5. Hasil Data Baseline durasi bermain game online

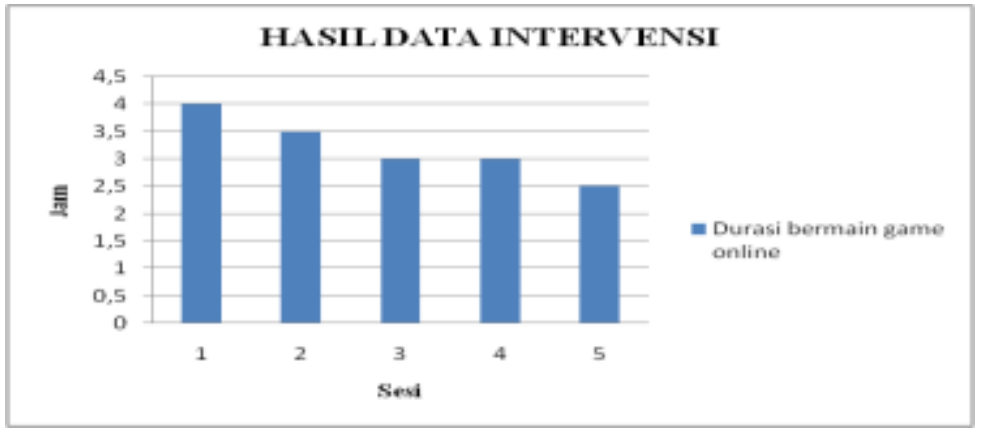

Gambar 6. Hasil Data Intervensi durasi bermain game online

Dari hasil data baseline dan intervensi diatas, jika data tersebut dapat dianalisis maka menjadi seperti tabel 9.

Tabel 9. hasil analisis data durasi bermain game online

\begin{tabular}{clcc}
\hline \multirow{2}{*}{ No } & \multirow{2}{*}{ Komponen analisis data } & \multicolumn{2}{c}{ Kondisi } \\
\cline { 3 - 4 } & & Baseline & Intervensi \\
\hline 1 & Panjang kondisi & 5 & 5 \\
2 & Estimasi kecenderungan arah & Menaik & Menurun \\
3 & Kecenderungan stabilitas & $82 \%$ (tidak stabil) & 100 (stabil) \\
4 & Level stabilitas & $4,5-6$ (tidak stabil) & $2,5-4$ (stabil) \\
5 & Level perubahan & $-1,5$ (memburuk) & $+2,5$ (membaik)
\end{tabular}


2. Perilaku berbohong

Tabel 10 Hasil data baseline frekuensi berbohong kepada orang tua

\begin{tabular}{cc}
\hline $\begin{array}{c}\text { Baseline } \\
\text { Sesi }\end{array}$ & $\begin{array}{c}\text { Frekuensi berbohong } \\
\text { kepada orangtua }\end{array}$ \\
\hline 1 & 3 \\
2 & 3 \\
3 & 4 \\
4 & 5 \\
5 & 5 \\
\hline
\end{tabular}

Tabel 11 Hasil data intervensi frekuensi berbohong kepada orang tua

\begin{tabular}{cc}
\hline $\begin{array}{c}\text { Intervensi } \\
\text { Sesi }\end{array}$ & $\begin{array}{c}\text { Frekuensi berbohong } \\
\text { kepada orangtua }\end{array}$ \\
\hline 1 & 2 \\
2 & 2 \\
3 & 1 \\
4 & 0 \\
5 & 0 \\
\hline
\end{tabular}

Data-data diatas jika divisualisasikan ke dalam bentuk grafik akan berbentuk seperti gambar dibawah ini:

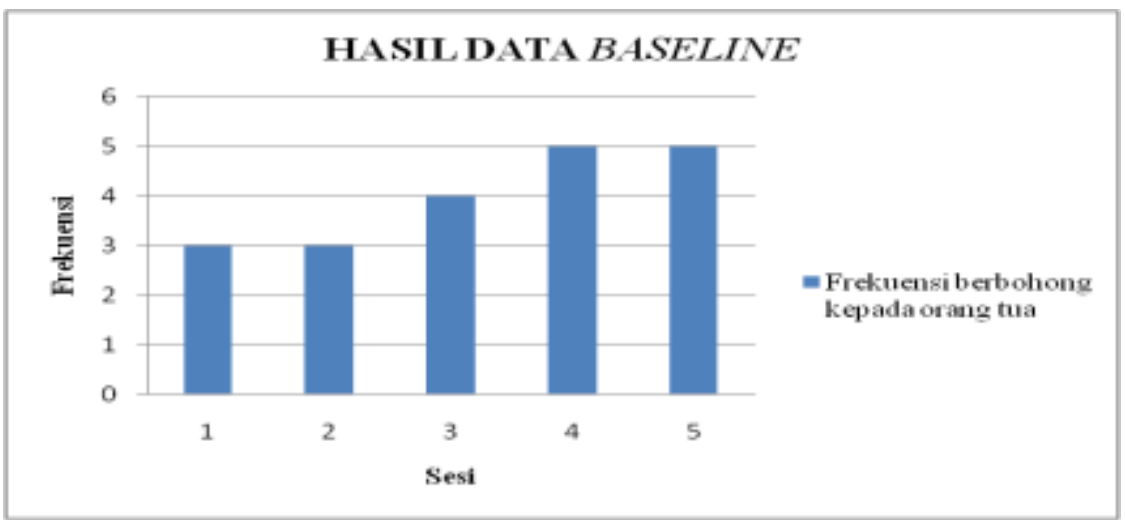

Gambar 7 Hasil data baseline berbohong kepada orang tua

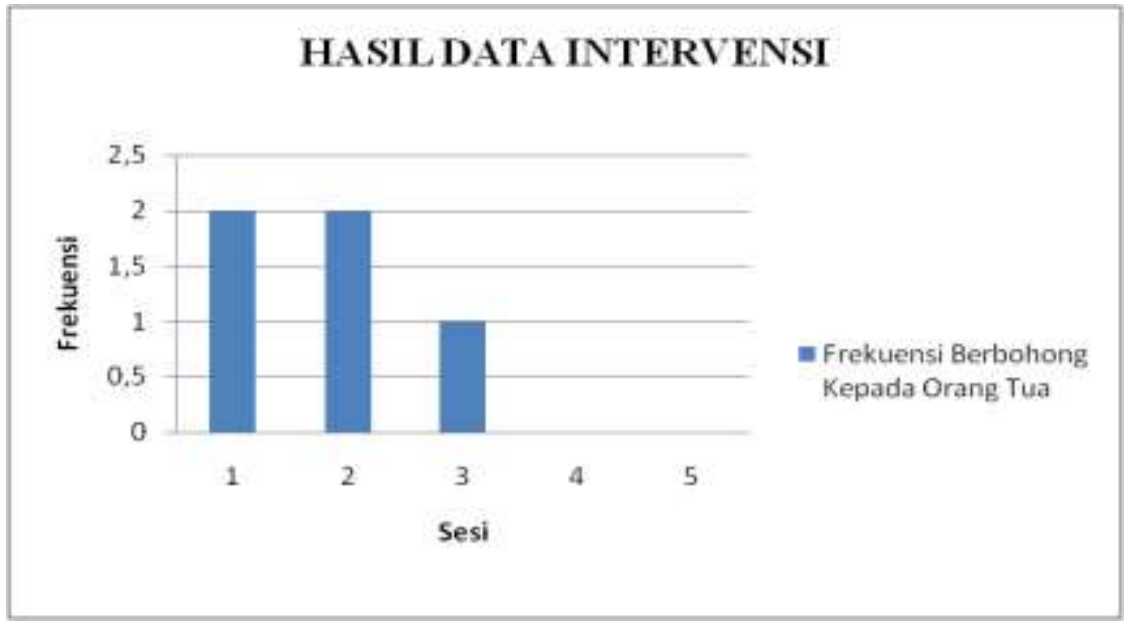

Gambar 8. Hasil data intervensi frekuensi berbohong kepada orang tua 
Dari hasil data baseline dan intervensi diatas, jika data tersebut dapat dianalisis maka menjadi seperti tabel 12 .

\begin{tabular}{llcc}
\multicolumn{2}{c}{ Tabel 12. hasil analisis data frekuensi berbohong kepada orang tua } \\
\hline \multirow{2}{*}{ No } & Komponen analisis data & \multicolumn{2}{c}{ Kondisi } \\
\cline { 3 - 4 } & & Baseline & Intervensi \\
\hline 1 & Panjang kondisi & 5 & 5 \\
2 & Estimasi kecenderungan arah & Menaik & Menurun \\
3 & Kecenderungan stabilitas & $85 \%$ (stabil) & 100 (stabil) \\
4 & Level stabilitas & $3-5$ (stabil) & $0-2$ (stabil) \\
5 & Level perubahan & -2 (memburuk) & +2 (membaik) \\
\hline
\end{tabular}

3. Perilaku berkelahi dengan saudara

Tabel 13. Hasil data baseline frekuensi berkelahi dengan anggota keluarga/saudara

\begin{tabular}{cc}
\hline $\begin{array}{c}\text { Baseline } \\
\text { Sesi }\end{array}$ & $\begin{array}{c}\text { Frekuensi berkelahi dengan } \\
\text { anggota keluarga/saudara }\end{array}$ \\
\hline 1 & 3 \\
2 & 3 \\
3 & 3 \\
4 & 3 \\
5 & 3 \\
\hline
\end{tabular}

Tabel 14 Hasil data intervensi frekuensi berkelahi dengan anggota keluarga/saudara

\begin{tabular}{cc}
\hline $\begin{array}{c}\text { Intervensi } \\
\text { Sesi }\end{array}$ & $\begin{array}{c}\text { Frekuensi berkelahi dengan } \\
\text { anggota keluarga/saudara }\end{array}$ \\
\hline 1 & 2 \\
2 & 1 \\
3 & 1 \\
4 & 0 \\
5 & 0 \\
\hline
\end{tabular}

Dari data-data yang berbentuk tabel diatas, apabila divisualisasikan kedalam bentuk grafik maka akan berbentuk seperti gambar 9 dan 10 .

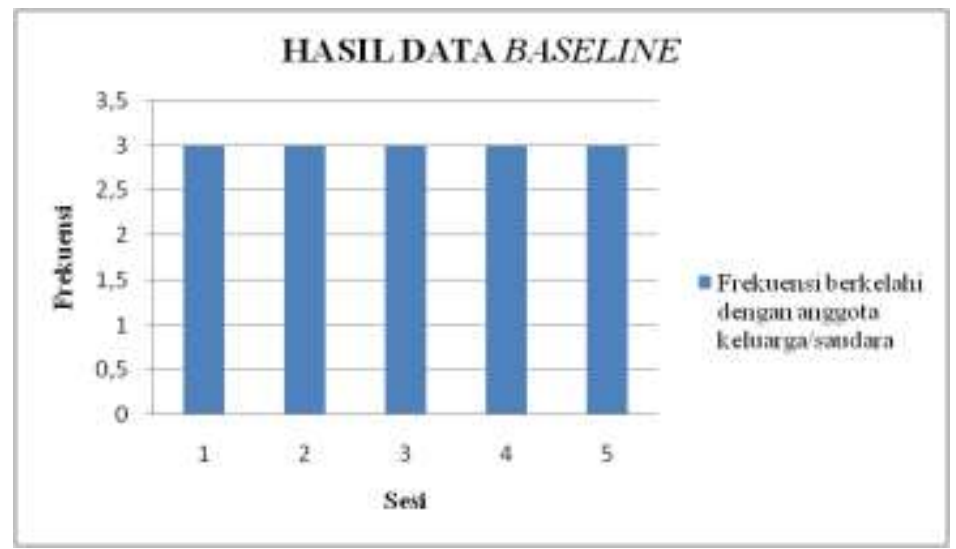

Gambar 9. Hasil data baseline frekuensi berkelahi dengan anggota keluarga/saudara 


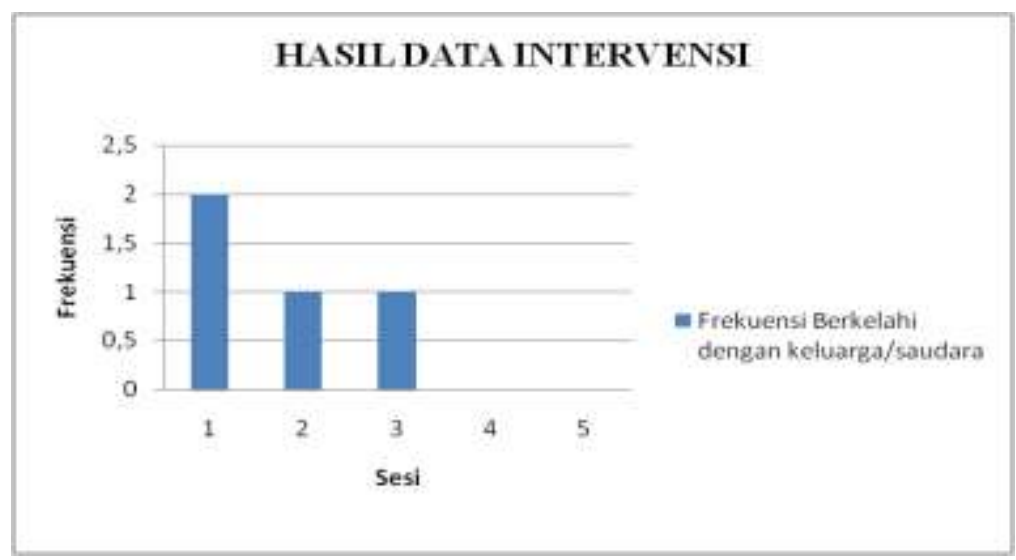

Gambar 10. Hasil data Intervensi frekuensi berkelahi dengan keluarga/saudara

Dari hasil data baseline dan intervensi diatas, jika data tersebut dapat dianalisis maka menjadi seperti tabel 16 .

Tabel 16. hasil analisis data frekuensi berkelahi dengan keluarga/saudara

\begin{tabular}{llcc}
\hline No & Komponen analisis data & \multicolumn{2}{c}{ Kondisi } \\
\cline { 3 - 4 } & & Baseline & Intervensi \\
\hline 1 & Panjang kondisi & 5 & 5 \\
2 & Estimasi kecenderungan arah & Menaik & Menurun \\
3 & Kecenderungan stabilitas & $91 \%$ (stabil) & 100 (stabil) \\
4 & Level stabilitas & $3-3$ (stabil) & $0-2$ (stabil) \\
5 & Level perubahan & 0 (memburuk) & +1 (membaik) \\
\hline
\end{tabular}

\section{Kesimpulan}

Berdasarkan hasil penelitian yang telah dilaksanakan, serta pembahasan penelitian mengenai penerapan konseling behavioral teknik modelling untuk mengatasi kecanduan game online pada anak usia 10 tahun (masa akhir kanak-kanak), maka dapat disimpulkan bahwa tingkat kecanduan game online yang dihinggapi anak termasuk dalam kondisi tinggi sebelum diberikan intervensi. Selain itu, kecanduan game online juga berdampak terhadap perilaku maladaptif yang muncul dalam diri anak yakni bermalas-malasan, berbohong kepada orangtua, serta berkelahi dengan keluarga/saudara karena game online. Tetapi, setelah peneliti memberikan intervensi berupa konseling behavioral teknik modelling selama enam pertemuan menunjukkan bahwa ada perubahan tentang tingkat kecanduan game online yang menjadi menurun dan perilaku-perilaku yang maladaptif berubah menjadi perilaku yang adaptif secara perlahan dan bertahap.

Pemberian konseling behavioral teknik modelling dengan stimulus berupa video dirasa tepat untuk mengatasi kecanduan game online serta dampak perilaku maladaptif yang muncul akibat dari kecanduan game online. Karena masa tumbuh kembang anak usia 6-11 tahun merupakan masa-masa yang haus akan pengetahuan baru yang didapatkan dari berbagai sumber. Dalam hal ini, video yang diberikan peneliti kepada subjek penelitian termasuk dalam pengetahuan baru yang didapatkan anak yang hal itu juga merupakan stimulus modelling untuk merubah perilaku maladaptif menjadi perilaku yang lebih adaptif. 


\section{Daftar Pustaka}

Amanda, R. A. (2016). Pengaruh Game Online Terhadap Perubahan Perilaku Agresif Remaja di Samarinda. EJournal Ilmu Komunikasi, 4(3), 290-304.

Corey, G. (2013). Theory and practice of counseling and psychotherapy. Theory and Practice of Counseling and Psychotherapy 5th Ed. https://doi.org/10.1016/0022-3999(94)901236

Fauziah, E. R. (2013). Pengaruh game online terhadap perubahan perilaku anak SMP Negeri 1 Samboja.

Habsy, B. A. (2014). Teori Dan Pendekatan Konseling Modern Dan Post Modern. Jombang: Undar Press.

Habsy, B. A. (2017a). Filosofi Ilmu Bimbingan dan Konseling Indonesia. Jurnal Pendidikan (Teori Dan Praktik), 2(1), 1. https://doi.org/10.26740/jp.v2n1.p1-11

Habsy, B. A. (2017b). Model Konseling Kelompok Cognitive Behavior untuk Meningkatkan Self Esteem Siswa Smk. Perspektif Ilmu Pendidikan, 31(1), 21. https://doi.org/10.21009/PIP.311.4

Habsy, B. A. (2017c). Seni Memahami Penelitian Kuliatatif dalam Bimbingan dan Konseling : Studi Literatur. Jurnal Konseling Andi Matappa, 1(2), 90-100. Retrieved from https://www.neliti.com/publications/177169/seni-memehami-penelitian-kuliatatifdalam-bimbingan-dan-konseling-studi-literatu

Habsy, B. A. (2018). Model Bimbingan Kelompok PPPM Untuk Mengembangkan Pikiran Rasional Korban Bullying Siswa SMK Etnis Jawa. Jurnal Pendidikan (Teori Dan Praktik), 2(2), 91. https://doi.org/10.26740/jp.v2n2.p91-99

Hurlock, E. B. (1980). Psikologi Perkembangan. Jakarta: Penerbit Erlangga.

Maulana, E. (2012). Faktor-Faktor Yang Mempengaruhi Perubahan Perilaku Sosial Remaja Terhadap Orang Tua Di Desa Labuhan Ratu Pasar Kecamatan Sungkai Selatan Kabupaten Lampung Utara Provinsi Lampung. Universitas Lampung.

Prastyo, Y. (2017). Pembagian Tingkat Kecanduan Game Online menggunakan K-Means Clustering serta Korelasinya terhadap Prestasi Akademik. Elinvo (Electronics, Informatics, and Vocational Education), 2(2), 138. https://doi.org/10.21831/elinvo.v2i2.17307

Runtukahu, J. T. (2013). Analisis Perilaku Terapan Untuk Guru. Yogyakarta: Ar-Ruzz Media.

Sanditaria, W. (2012). Adiksi Bermain Game Online pada Anak Usia Sekolah di Warung Internet Penyedia Game Online Jatinangor Sumedang. Students E-Journal, 1(1), 32. Retrieved from http://journal.unpad.ac.id/ejournal/article/view/745

Santoso, Y. R. D. (2016). Hubungan Kecanduan Game Online Dota 2 terhadap Penyesuaian Sosial pada Remaja. Program Studi Psikologi FPSI-UKSW. Retrieved from http://repository.uksw.edu/handle/123456789/13126 
